\title{
Massive basalt flows on the southern flank of Tamu Massif, Shatsky Rise: a reappraisal of ODP Site 1213 basement units ${ }^{1}$
}

\author{
A.A.P. Koppers, ${ }^{2}$ T. Sano, ${ }^{3}$ J.H. Natland, ${ }^{3}$ M. Widdowson, ${ }^{3}$ R. Almeev, ${ }^{3}$ A.R. Greene, ${ }^{3}$ D.T. Murphy, ${ }^{3}$
} A. Delacour, ${ }^{3}$ M. Miyoshi, ${ }^{3}$ K. Shimizu, ${ }^{3}$ S. Li, ${ }^{3}$ N. Hirano, ${ }^{3}$ J. Geldmacher, ${ }^{3}$ and the Expedition 324 Scientists $^{3}$

\section{Chapter contents}

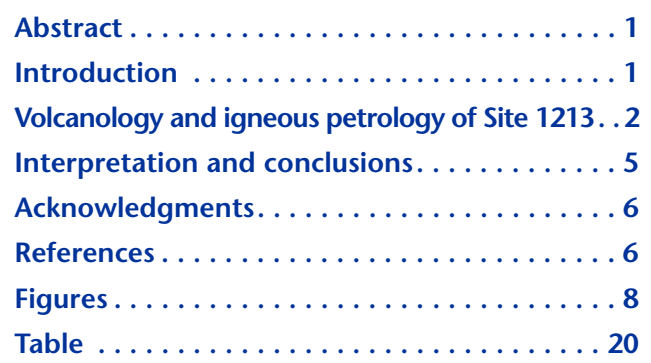

${ }^{1}$ Koppers, A.A.P., Sano, T., Natland, J.H., Widdowson, M., Almeev, R., Greene, A.R., Murphy, D.T., Delacour, A., Miyoshi, M., Shimizu, K., Li, S., Hirano, N., Geldmacher, J., and the Expedition 324 Scientists, 2010. Massive basalt flows on the southern flank of Tamu Massif, Shatsky Rise: a reappraisal of ODP Site 1213 basement units. In Sager, W.W., Sano, T., Geldmacher, J., and the Expedition 324 Scientists, Proc. IODP, 324: Tokyo (Integrated Ocean Drilling Program Management International, Inc.). doi:10.2204/iodp.proc.324.109.2010

${ }^{2}$ College of Oceanic and Atmospheric Sciences, Oregon State University, 104 COAS Administration Building, Corvallis OR 97331-5503, USA. akoppers@coas.oregonstate.edu ${ }^{3}$ Expedition 324 Scientists' addresses.

\section{Abstract}

Drilling during Ocean Drilling Program Leg 198 at Site 1213 recovered three massive basalt units (8-15 $\mathrm{m}$ thick) from the southern flank of Tamu Massif at Shatsky Rise. Originally, these igneous units were interpreted to represent three diabase sills. During Integrated Ocean Drilling Program Expedition 324, this core was redescribed leading to the new conclusion that these diabase units represent three submarine massive basalt flows. These massive submarine flows were probably emplaced as inflated compound sheet flows during eruptions similar to those in large oceanic plateaus and continental flood basalts.

\section{Introduction}

The main objective of Integrated Ocean Drilling Program (IODP) Expedition 324 was to test competing mantle plume and plate tectonic models for ocean plateau formation at Shatsky Rise (Fig. F1). In these tests, determining the timing, duration, and source of volcanism at Shatsky Rise is of pivotal importance to understand the origin of this oceanic plateau. A short time span of volcanism less than a few millions of years would imply a plume head-like eruption (e.g. Campbell, 2007; Courtillot et al., 2003), and a southwest to northeast age progression along Shatsky Rise would suggest a transition from plume head to plume tail. On the contrary, a longer duration of volcanism forming the Tamu, Ori, and Shirshov massifs at Shatsky Rise (Fig. F1) would indicate much lower rates of lava effusion that are more consistent with alternative ridge-controlled mechanisms and the effects of rapid upwelling at a ridge-ridge-ridge triple junction. In the latter cases, estimation of source temperatures and degree of partial melting will prove important in showing the possibility of shallower mantle sources and testing associated extreme mantle fertility melting models (e.g., Anderson, 1995; Foulger, 2007).

As a large igneous province (LIP), Shatsky Rise currently is an enigma in the Earth sciences because it has characteristics consistent with both a deep mantle plume and that of a shallow mantle source controlled by plate tectonic processes. Its large volume and apparently rapid eruption of the entire volcanic pile are a possible consequence of a massive plume head impinging at the base of the Pacific lithosphere at 146 Ma (Sager and Han, 1993; Mahoney et al., 2005). Yet, lava compositions with mid-ocean-ridge 
basalt type signatures found in previously drilled Shatsky Rise basalt units (Mahoney et al., 2005) may provide evidence pointing to a shallow mantle source. Importantly, Shatsky Rise represents only one of the very few places in the world oceans where we can distinguish between these two end member models. Because $\mathrm{M}$-series magnetic anomalies are preserved in the Jurassic to Late Cretaceous ocean crust surrounding Shatsky Rise, the buildup of this large ocean plateau can be directly compared in space and time with the formation of ancient segments of oceanic plate. Drilling of volcanic basement at five sites, from the oldest Tamu Massif ( 146 Ma; Mahoney et al. 2005) to the younger Ori Massif and Shirshov Massif ( 140 Ma), provides us with critical samples that will help us distinguish between the mantle plume and plate tectonic models.

Ocean Drilling Program (ODP) Leg 198, which sailed in 2001, was the first expedition to penetrate into igneous basement of Shatsky Rise at Site 1213 on the southwest flank of Tamu Massif (Fig. F1). Drilling extracted $46.6 \mathrm{~m}$ of basaltic rock at a high recovery of $72.3 \%$ (Shipboard Scientific Party, 2002). This site is important to the testing of the two models of formation as it may contain older eruptive sequences than lavas drilled during Expedition 324. Drilling at Site 1213 recovered three massive basalt units $(8-15 \mathrm{~m}$ thick) originally interpreted to represent three diabase sills (Shipboard Scientific Party, 2002). During Expedition 324 and the first postcruise scientific meeting in College Station, Texas (USA), the Expedition Scientists, including igneous petrologists, volcanologists, alteration specialists, and structural geologists, redescribed all Site 1213 igneous basement cores and processed all this information using the new Laboratory Information Management System (LIMS) database. The principal outcome of this reappraisal was the reinterpretation of these diabase units as three submarine massive basalt flows, similar to those found in other LIPs and flood basalts. In this study we provide macroscopic and petrographic descriptions, some limited shipboard measurements, and a reappraisal of the basement units cored at Site 1213.

\section{Volcanology and igneous petrology of Site 1213}

Hole $1213 \mathrm{~B}$ is located $\sim 200 \mathrm{~km}$ southwest of Site U1347 on the eastern flank of Tamu Massif and 400 $\mathrm{km}$ south of Site U1348 on the northeastern high (Fig. F1). Volcanic rocks recovered at Site 1213 were only sparsely sampled and studied (e.g., Mahoney et al., 2005), yet this site obviously complements the drilling objectives of Expedition 324.
In this report we briefly describe the major lithologies of the basement sequence and their petrography. On board, the core sections were digitally imaged and measurements of point-source susceptibility and optical reflectance were acquired at $1 \mathrm{~cm}$ intervals. New lithologic units were assigned, and the basement rocks were described macroscopically for volcanological structures, igneous petrology, and alteration. Microscopic descriptions and digital photomicrographs were made from nine thin sections from Leg 198 available to the scientists onboard. All of this new shipboard data was entered into LIMS. To distinguish our new data and observations from those obtained during Leg 198, Expedition 324(198), Site U1213, and Hole U1213B are the sample identifiers used in the databases according to IODP policy. However, in this report the prefix " $U$ " will not be used. Detailed visual core description reports were automatically generated from the shipboard database entries (see "Site 1213 visual core descriptions" in "Core descriptions"). The major lithologic features of each unit are summarized in Figures F2, F3, and F4.

\section{Physical volcanology}

During Leg 198, the igneous basement unit (IV) of Hole 1213B was divided on the basis of lithologic patterns into three stratigraphic subunits (IVa-IVc) separated by intercalated sediments and interpreted as "diabase sills" (Shipboard Scientific Party, 2002). In a similar fashion, we divided the Hole 1213B volcanic basement into nine lithologic units (1-9) based on the presence of sediments (including some displaced dropstones fallen into the hole from the sediment sections above) and variations in the basaltic groundmass grain size (Table T1). We have combined these lithologic units into three stratigraphic subunits representing three individual cooling units as thick as $15 \mathrm{~m}$ : Subunit IVa is composed of six lithologic units (1-6), whereas Subunits IVb and IVc correspond to lithologic Units 7 and 9, respectively. Lithologic Unit 8 is a fragment of intercalated sediment between Units 7 and 9. All three cooling units are characterized by a finer grained top and base, indicating they are more likely massive submarine basaltic lava flows (see the "Methods" chapter) and not sills.

\section{First massive basalt flow (stratigraphic Subunit IVa; lithologic Units 1-6)}

Subunit IVa is a $14.3 \mathrm{~m}$ thick massive basalt flow. This basement unit consists of typically nonvesicular, aphyric to moderately phyric, cryptocrystalline to fine-grained basalts that are slightly to moderately altered. The top of the unit is bounded by overlying 
sedimentary rocks with "baked" chert (indicated by dark discoloration of the chert near contact with the igneous rocks) at interval 324(198)-1213B-28R-1, 17 $\mathrm{cm}$. Although a glassy rim is not identified at the top of the unit, a cryptocrystalline chill zone $\sim 10 \mathrm{~cm}$ thick is present. The base of Unit IVa is defined by a narrow cryptocrystalline chill zone that also is $\sim 10$ $\mathrm{cm}$ thick and by a lithified/baked sedimentary contact at interval 324(198)-1213B-30R-4, $66 \mathrm{~cm}$. Toward the interior of this massive basalt flow grain sizes increase to fine grained. In the cryptocrystalline and microcrystalline portions, a small amount $(<6$ vol\%) of plagioclase and clinopyroxene microphenocrysts are present, commonly forming glomerocrysts, yet these microphenocrysts could not be identified in the coarser grained interior of the basalt flow where the groundmass crystals have comparable sizes. Phenocrysts are typically subhedral and their size ranges from 0.2 to $0.5 \mathrm{~mm}$.

Sedimentary rocks (lithologic Units 3 and 5) occur at two intervals within Unit IVa (intervals 324(198)1213B-29R-1, 0-13 cm, and 30R-1, 10-17 cm). These rocks are probably loose pieces of drilling rubble because we could not see either chill zone or grain size variation within the igneous rocks surrounding the sedimentary rocks.

\section{Second massive basalt flow (stratigraphic Subunit IVb; lithologic Unit 7)}

This second massive flow unit is $14.6 \mathrm{~m}$ thick, nonvesicular, and aphyric to glomeroporphyritic and ranges in grain size from cryptocrystalline to finegrained basalts. These basalts are only slightly to moderately altered. This unit is bounded at the top and base by sedimentary rocks and has both upper and lower chill zones with cryptocrystalline basalts. The lower chill zone consists of fragmented (and partly brecciated) basalts in interval 324(198)-1213B$32 \mathrm{R}-4,62-70 \mathrm{~cm}$. Thicknesses of both upper and lower chill zones are $\sim 10 \mathrm{~cm}$, and altered glass rind up to $1 \mathrm{~mm}$ wide is also identified in the lower chill zone. Grain size increases to fine grained away from the chill zones and into the flow interior. Subhedral plagioclase and clinopyroxene phenocrysts are present only as glomerocrysts $5-12 \mathrm{~mm}$ in size. Sparse but frequent glomerocrysts are scattered throughout the interior of the massive flow. We observed several vertical fractures that are filled with calcite and clay minerals in the interior, implying that this is indeed a large cooling unit.

\section{Third massive basalt flow (stratigraphic Subunit IVc; lithologic Unit 9)}

The third massive basalt flow is at least $11.3 \mathrm{~m}$ thick and has a similar nonvesicular, aphyric to glom- eroporphyritic character to that of the overlying Subunits IVa and IVb. Both plagioclase and clinopyroxene phenocrysts are subhedral and as large as 10 $\mathrm{mm}$. The top of this unit is defined by an overlying sedimentary rock unit (lithologic Unit 8) and is marked by the presence of a chill zone $\sim 20 \mathrm{~cm}$ thick. The top of the chill zone consists of fragmented cryptocrystalline basalts in interval 324(198)-1213B32R-4, 77-85 cm. Immediately adjacent to the fragmented basalts is a chill zone that has a small amount of vesicles (interval 324(198)-1213B-32R-4, $85-94 \mathrm{~cm}$ ). The vesicles are now filled with amygdules of calcite and clay minerals. The interior of the massive flow is fine-grained basalt with several fractures, and it extends to the end of the recovered core in interval 324(198)-1213B-33R-3, $130 \mathrm{~cm}$.

\section{Petrography}

During Leg 198, nine polished thin sections were prepared from basaltic rocks of Hole 1213B. Seven thin sections came from the interiors of cooling units and two from margins. From the outset of our reappraisal, we addressed the question of whether the cooling units were extrusive (pillows or flows) or, as described in the Leg 198 Scientific Results, intrusive (sills). Our lithologic descriptions suggest the former, and this is confirmed by petrography.

In thin section, the rocks are all nonvesicular plagioclase-clinopyroxene microphyric basalt and show no significant changes in these essential characteristics throughout. Differences in grain size, crystal morphologies, and crystallinity, however, are important depending on distance from the margins in these extrusive units (Fig. F5). These differences depend on the profound differences in cooling rate experienced by individual lava flows (pillow) that erupted under water from their margins, which typically quench to glass, to their interiors, which may have been sufficiently far from the interface with seawater to crystallize to fairly coarse grain size, similar to lava flows on land. Consequently, the procedure of describing pillow lavas from rims to interiors (e.g., Kirkpatrick, 1979; Natland, 1979, 1980) using the terminology for crystal morphologies developed on the basis of controlled cooling experiments (e.g., Lofgren, 1971; Kirkpatrick, 1975) is adopted here. Differences in cooling rate and mineral type, and consequently crystal morphologies, are typically greatest within the outer few centimeters of the extrusive boundaries, changing from spherulitic to fibrous, needle-like, acicular, dendritic and skeletal, and finally tabular with increasing distance from glassy margins, reaching as far away as $30 \mathrm{~cm}$ in lava flow and pillow interiors. The rocks of Hole 1213B, however, attain a fairly consistent and relatively coarse grain size in 
the centers of extrusive units as thick as $12 \mathrm{~m}$, which attests to chemical similarity and perhaps fairly low cooling rates. The rocks can thus be described as a single petrographic type.

\section{Spherulites at the rim}

A submarine extrusive origin is confirmed in one instance by the occurrence of coalesced and bow-tie spherulites (pillow Zones 4 and 5 of Kirkpatrick, 1979) at the margin of Thin Section 47 (Sample 324(198)-1213B-31R-1, 2-7 cm), whereas Zones 1-3 (glass, isolated plagioclase spherulites, and partly coalesced spherulites) are missing. The plagioclase fibers in the spherulites become thicker and more distinctive with distance from the rim (Fig. F6), with titanomagnetite crystals also becoming larger. The titanomagnetite is very small and dispersed at the rim (Fig. F6A), partially concentrated at the ends of sheaflike plagioclase spherulites (Fig. F6B), and then scattered between almost randomly oriented acicular and skeletal plagioclase needles at a distance of $\sim 20$ $\mathrm{mm}$ from the rim (Fig. F6C).

\section{Olivine}

Olivine occurs in only one thin section of the pillow rim described above. Several isolated euhedra occur in one portion of the pillow margin and are now completely replaced by dull greenish brown clays.

\section{Plagioclase and pyroxene crystal growth}

Within the finer grained rims of the basaltic cooling units, the spherulitic mesostasis contains wellformed crystals (often euhedral) of plagioclase and clinopyroxene microphenocrysts, plus some microglomerophyric intergrowths of the two minerals. Most of the plagioclase is elongate, forming only slightly skeletal laths that do not have dendritic terminations (Fig. F7A, F7B). These crystals were present in the molten liquid prior to eruption and during eruption grew into their present elongate morphologies, yet at these more extreme cooling rates, they did not radiate into sheaf spherulites at their ends. Further into the flow interiors, elongate microphenocrysts like this are not present and plagioclase crystals instead are more equant.

Clinopyroxene ranges from small euhedral crystals (Fig. F8) to somewhat larger grains, some of which are sector zoned (Fig. F8B). Along with plagioclase, these crystals were present before eruption, growing into their present morphologies in the quickly cooled rims, despite extremely high cooling rates and the absence of clinopyroxene dendrites among the spherulitic plagioclase fibers.
Both individual crystals and crystal clumps of clinopyroxene and plagioclase can be traced into the flow interiors. However, the shapes of the crystals become irregular and microphenocrysts virtually disappear against the coarser grained groundmass. This transition can be seen especially well in the standard textural photomicrographs (Fig. F7) and mainly results from the larger crystal sizes in the interior of the cooling units and an increasingly equant tabular form of the groundmass plagioclase. In the flow interiors, plagioclase arrays can be somewhat stellate, with clinopyroxene crystals developed between the arms, but overall these textures represent the development of an interlocking network of plagioclase-clinopyroxene crystal clumps, with dark and now altered intersertal spaces in between.

\section{Coarse crystal clots}

A number of rocks have what might be termed "gabbroic" coarse aggregates consisting mainly of interlocking plagioclase crystals (Fig. F9E). Two of these clots occur in Thin Section 51 (Sample 324(198)1213B-32R-4, 131-134 cm). One clot, consisting of a single large plagioclase crystal, is shown in Figure F9C and F9D, and another (Fig. F9E) is the more exemplary multicrystal intergrowth, which occurs only a few millimeters away. Both have external overgrowths, with skeletal rims of normally zoned plagioclase, that grew from melt in the adjacent finer grained matrix as it crystallized after eruption. Both also have numerous melt inclusions, now altered. Most of the inclusions are very tiny and round, but others are irregular in shape, with outlines suggesting skeletal growth of the crystals. The crystal interiors enclose both altered glass and titanomagnetite (Fig. F9F).

\section{Titanomagnetite}

Titanomagnetite is the only magmatic oxide mineral. Its size, from finest to coarsest, and from extrusive margin to flow interior, probably spans three orders of magnitude. In finely spherulitic material, titanomagnetite appears as tiny specks of almost unresolvable morphology when seen in transmitted light (Fig. F7A, F7B), with only the largest of these crystals verging on skeletal in outline. In more coarsely crystalline interiors of the extrusive units, titanomagnetite invariably occurs in intersertal spaces that once were glassy but are now altered. In such locations, it is always distinctly skeletal in morphology, ranging from small hopper-shaped crystals with euhedral outlines (Fig. F10A) to crystals of more irregular shape, including many that are intergrown with plagioclase (Fig. F10B, F10C). Skeletal morphol- 
ogies persist even in the largest crystals of the mineral (Fig. F10D), whereby titanomagnetite typically began growing together with plagioclase but finished its growth into the differentiating final melts in between crystals. Very long chains like this are rare and only occur in the larger intersertal spaces; a more space-limited elongate skeletal grain that happens to be rooted in clinopyroxene is shown in Figure F10E.

It thus appears that cooling rates in the interior of the extrusive massive lava flows were not very high, allowing large titanomagnetite crystals to grow with coarse skeletal morphologies. At all cooling rates, titanomagnetite joins the crystallization sequence after clinopyroxene and plagioclase coprecipitated, as it occurs either between crystals of plagioclase and clinopyroxene or intergrown with plagioclase. Intergrowths with plagioclase indicate saturation of latestage differentiating intersertal liquids with titanomagnetite.

\section{Intersertal crystallization}

Intersertal spaces between coarse-grained interlocking centers of intergrown plagioclase, clinopyroxene, and titanomagnetite are entirely replaced by clay minerals, which are generally dull orange-green in transmitted light. If this material was once glassy, the volcanic glass is now altered. If this material once contained finely crystalline crystals of silicate and oxide minerals, or sulfide globules, those are now replaced, too. Thin section images in reflected light reveal that a high percentage of the intersertal spaces have been altered to clays, as such materials are simply nonreflective and the polished primary mineral grains stand out against them (Fig. F10E).

\section{Alteration}

Basaltic rocks recovered from Hole 1213B have been affected by slight to moderate (5\%-25\%) low-temperature water-rock interactions resulting in a complete replacement of glassy mesostasis occupying the intersertal spaces (see above) and a slight to moderate replacement of plagioclase and clinopyroxene, present in the groundmass or as phenocrysts. Clay minerals (identified as brown and green clays) are the most abundant secondary phases in Hole 1213B, predominantly replacing the glassy mesostasis (Fig. F11A, F11B), slightly altering plagioclase and pyroxene micro- and phenocrysts, and filling veins. Calcite is a minor secondary phase observed only locally as replacement of the glassy mesostasis (Fig. F11C) and in association with green clays in veins. An example of plagioclase phenocryst alteration is shown in Figure F11D, where the rim of the previous igneous plagioclase has been replaced by a feldspar, possibly richer in $\mathrm{Na}$ and/or $\mathrm{K}$ in association with seric- ite. However, this kind of $\mathrm{K}$ feldspar after plagioclase alteration is not common in this core. Titanomagnetite, present in the groundmass, has also been slightly to moderately altered. Secondary pyrite is widespread throughout the basalt and present in the groundmass and in veins. No fresh glass was observed on flow margins. Three main types of veins occur in Hole 1213B:

1. Calcite veins (predominant),

2. Green clay veins, and

3. Composite veins of calcite + green clays \pm pyrite.

There is an average of $\sim 3$ veins $/ \mathrm{m}$ in the basement lavas, and average vein thickness is $\sim 1 \mathrm{~mm}$. Calcite veins show two main morphologies, blocky and fibrous, which can both be present in a single vein (Fig. F11E). Alteration of basaltic rocks at Site 1213 is interpreted to result from interaction with seawaterderived fluids at relatively low temperature and is similar to what has been observed and described in Hole U1347A (north of Tamu Massif; see the "Site U1347" chapter).

\section{Interpretation and conclusions}

The Shipboard Scientific Party (2002) of Leg 198 reported that the igneous rocks recovered from Hole 1213B are intrusive sills, using three arguments based on previous ODP cruise results:

1. Extrusive lava flows are usually accompanied by highly fractured and brecciated flow tops, yet these phenomena are rare or absent in the basement rocks of Hole 1213B;

2. Extrusive lava flows generally have thin (or no) chilled margins, yet chill zones exist and are relatively thick (as thick as $\sim 20 \mathrm{~cm}$ ) in Hole 1213B; and

3. Gradational changes in crystallinity toward coarsely crystalline interiors are typical of mafic sill intrusions.

However, from our careful descriptions we conclude that the Hole 1213B igneous rocks are massive submarine lava flows based on the following observations:

1. Although highly fractured and brecciated rock is not common in the igneous rocks of Hole 1213B, part of the lower chill zone in stratigraphic Subunit IVb is weakly brecciated in interval 324(198)-1213B-32R-4, 62-65 cm, indicating that this zone is presumably the base of a submarine lava flow. Several fragments in the lower chill zone of Subunit IVb and upper chill zone of Subunit IVc are likely autobrecciated fragments typically found associated with the eruption as lava flows. 
2. The relatively thick chill zones in Hole $1213 \mathrm{~B}$ are also seen in similar massive flows cored at ODP Leg 192 Sites 1185 and 1186 on Ontong Java Plateau (Mahoney, Fitton, Wallace, et al., 2001). For example, the thickest massive lava flow of Site 1186 has a $\sim 20 \mathrm{~cm}$ thick cryptocrystalline chill zone at the top of lithologic Unit 4.

3. Thin section descriptions of the chill zones and interiors of all three cooling units suggest that the cooling units have a submarine origin, as is confirmed in one instance by the occurrence of coalesced and bow-tie spherulites. Systematic differences in grain size, crystal morphologies and crystallinity are apparent in all three cooling units from the chill zones to the more crystalline and coarse-grained interiors and point into the direction of massive extrusive basalt flows.

In this report, we thus specifically note that the three cooling units are more likely to represent "massive lava flows" instead of a series of "sills" as described in the Site 1213 chapter in Leg 198 Scientific Results (Shipboard Scientific Party, 2002). Seismic profiles from site survey Cruise TN037 (Klaus and Sager, 2002; Sager et al., 2009) over the flank of Tamu Massif also show that massive flows are present all the way down the southwest flank and beyond Site 1213. Therefore, the massive submarine flows (as thick as $15 \mathrm{~m}$ ) were probably emplaced as inflated compound sheet flows during eruptions similar to those in large oceanic plateaus (Greene et al., 2010) and continental flood basalts (e.g., Self et al., 1997) worldwide. The flows likely erupted from a limited number of fissures along the flank of Shatsky Rise and may have traveled a long distance. Massive flows in oceanic plateaus are generally $<15 \mathrm{~m}$ thick (Nixon et al., 2008), similar to the thicknesses of the three massive flow units at Site 1213. From comparative land studies in submarine flood basalt provinces, it is evident that massive submarine flows are rarely marked by amygdaloidal horizons or brecciated flow tops and that flow contacts are not easily discernible where interflow sediments are absent (Greene et al., 2009).

\section{Acknowledgments}

This research used data provided by the Integrated Ocean Drilling Program (IODP).

\section{References}

Anderson, D.L., 1995. Lithosphere, asthenosphere, and perisphere. Rev. Geophys., 33(1):125-149. doi:10.1029/ 94RG02785
Campbell, I.H., 2007. Testing the plume theory. Chem. Geol., 241(3-4):153-176. doi:10.1016/j.chemgeo.2007.01.024

Courtillot, V., Davaille, A., Besse, J., and Stock, J., 2003. Three distinct types of hotspots in Earth's mantle. Earth Planet. Sci. Lett., 205(3-4):295-308. doi:10.1016/S0012821X(02)01048-8

Foulger, G.R., 2007. The "plate" model for the genesis of melting anomalies. In Foulger, G.R., and Jurdy, D.M. (Eds.), Plates, Plumes, and Planetary Processes. Spec. Pap.-Geol. Soc. Am., 430:1-28.

Greene, A.R., Scoates, J.S., Weis, D., Nixon, G.T., and Kieffer, B., 2009. Melting history and magmatic evolution of basalts and picrites from the accreted Wrangellia oceanic plateau, Vancouver Island, Canada. J. Petrol., 50(3):467-505. doi:10.1093/petrology/egp008

Greene, A.R., Scoates, J.S., Weis, D., Katvala, E.C., Israel, S., and Nixon, G.T., 2010. The architecture of oceanic plateaus revealed by the volcanic stratigraphy of the accreted Wrangellia oceanic plateau. Geosphere, 6(1):4773. doi:10.1130/GES00212.1

Kirkpatrick, R.J., 1975. Crystal growth from the melt: a review. Am. Mineral., 60(9-10):798-814.

Kirkpatrick, R.J., 1979. Processes of crystallization in pillow basalts, Hole 396B, DSDP Leg 46. In Dmitriev, L., Heirtzler, et al., 1979. Init. Repts. DSDP, 46: Washington, DC (U.S. Govt. Printing Office), 271-282. doi:10.2973/ dsdp.proc.46.117.1979

Klaus, A., and Sager, W.W., 2002. Data report: high-resolution site survey seismic reflection data for ODP Leg 198 drilling on Shatsky Rise, northwest Pacific. In Bralower, T.J., Premoli Silva, I., Malone, M.J., et al., Proc. ODP, Init. Repts., 198: College Station, TX (Ocean Drilling Program), 1-21. doi:10.2973/odp.proc.ir.198.111.2002

Lofgren, G., 1971. Spherulitic textures in glassy and crystalline rocks. J. Geophys. Res., [Solid Earth], 76(23):56355648. doi:10.1029/JB076i023p05635

Mahoney, J.J., Duncan, R.A., Tejada, M.L.G., Sager, W.W., and Bralower, T.J., 2005. Jurassic-Cretaceous boundary age and mid-ocean-ridge-type mantle source for Shatsky Rise. Geology, 33(3):185-188. doi:10.1130/ G21378.1

Mahoney, J.J., Fitton, J.G., Wallace, P.J., et al., 2001. Proc. ODP, Init. Repts., 192: College Station, TX (Ocean Drilling Program). doi:10.2973/odp.proc.ir.192.2001

Natland, J.H., 1979. Crystal morphologies in basalts from DSDP Site $395,23^{\circ} \mathrm{N}, 46^{\circ} \mathrm{W}$, Mid-Atlantic Ridge. In Melson, W.G., Rabinowitz, P.D., et al., Init. Repts. DSDP, 45: Washington, DC (U.S. Govt. Printing Office), 423-445. doi:10.2973/dsdp.proc.45.118.1979

Natland, J.H., 1980. Crystal morphologies in basalts dredged and drilled from the East Pacific Rise near $9^{\circ} \mathrm{N}$ and the Siqueiros Fracture Zone. In Rosendahl, B.R., Hekinian, R., et al., Init. Repts. DSDP, 54: Washington, DC (U.S. Govt. Printing Office), 605-634. doi:10.2973/ dsdp.proc.54.124.1980

Nixon, G.T., Laroque, J., Pals, A., Styan, J., Greene, A.R., and Scoates, J.S., 2008. High-Mg lavas in the Karmutsen 
flood basalts, northern Vancouver Island (NTS 092L): stratigraphic setting and metallogenic significance. In Geological Fieldwork 2007. Pap.-Minist. Energy, Mines Pet. Resour. (B. C.), 2008-1:175-190. http:// www.empr.gov.bc.ca/Mining/Geoscience/PublicationsCatalogue/Fieldwork/Documents/17Nixon24513.pdf

Sager, W.W., and Han, H.-C., 1993. Rapid formation of the Shatsky Rise oceanic plateau inferred from its magnetic anomaly. Nature (London, U. K.), 364(6438):610-613. doi:10.1038/364610a0

Sager, W.W., Sano, T., and Geldmacher, J., 2009. Testing plume and plate models of ocean plateau formation at
Shatsky Rise, northwest Pacific Ocean. IODP Sci. Prosp., 324. doi:10.2204/iodp.sp.324.2009

Self, S., Thordarson, T., and Keszthelyi, L., 1997. Emplacement of continental flood basalt lava flows. In Mahoney, J.J., and Coffin, M. (Eds.), Large Igneous Provinces: Continental, Oceanic, and Planetary Flood Volcanism. Geophys. Monogr., 100:381-410.

Shipboard Scientific Party, 2002. Site 1213. In Bralower, T.J., Premoli Silva, I., Malone, M.J., et al., Proc. ODP, Init. Repts., 198: College Station, TX (Ocean Drilling Program), 1-110. doi:10.2973/odp.proc.ir.198.109.2002

Published: 3 November 2010

MS 324-109 
Figure F1. Simple stratigraphic column of igneous section in Hole U1213B and Deep Sea Drilling Project (DSDP), Ocean Drilling Program (ODP), and Integrated Ocean Drilling Program (IODP) Expedition 324 site locations at Shatsky Rise. Inset illustrates the location of Shatsky Rise in relation to western Pacific magnetic lineations (thin lines), trenches (toothed line), and Japan. Stratigraphic column shows succession of stratigraphic units of Hole 1213B (see Figs. F2, F3, F4, and F5 for details).

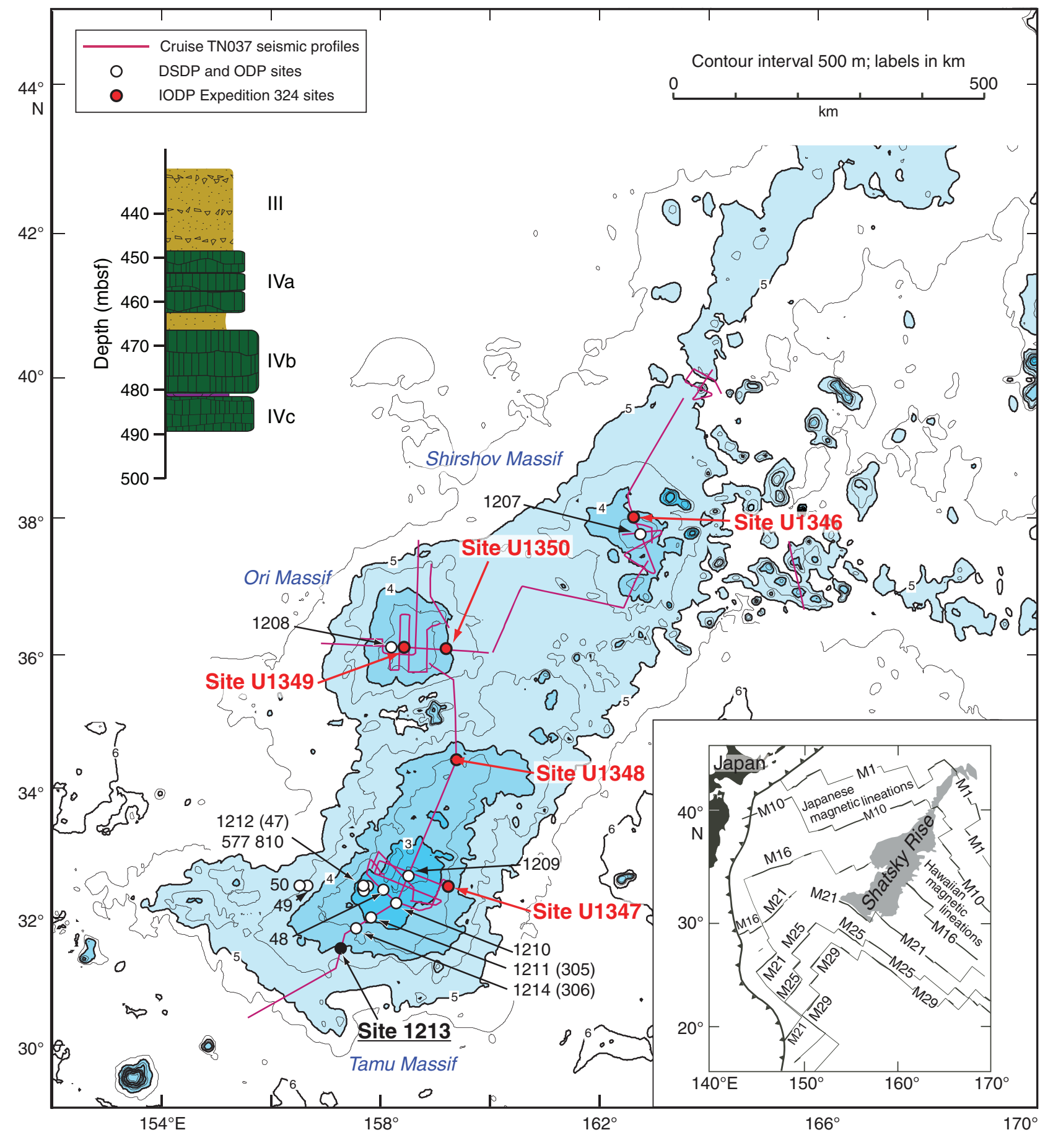


Figure F2. Lithologic summary of the interval of sampling in Hole 1213B. Interestingly, magnetic susceptibility is higher in the interiors of the three massive lava flows in Hole 1213B and gradually lower toward the top and base of each flow, where petrography analyses indicates smaller crystal sizes for titanomagnetite, the sole oxide mineral observed in these basaltic flows and thus likely the carrier of the magnetic signal.

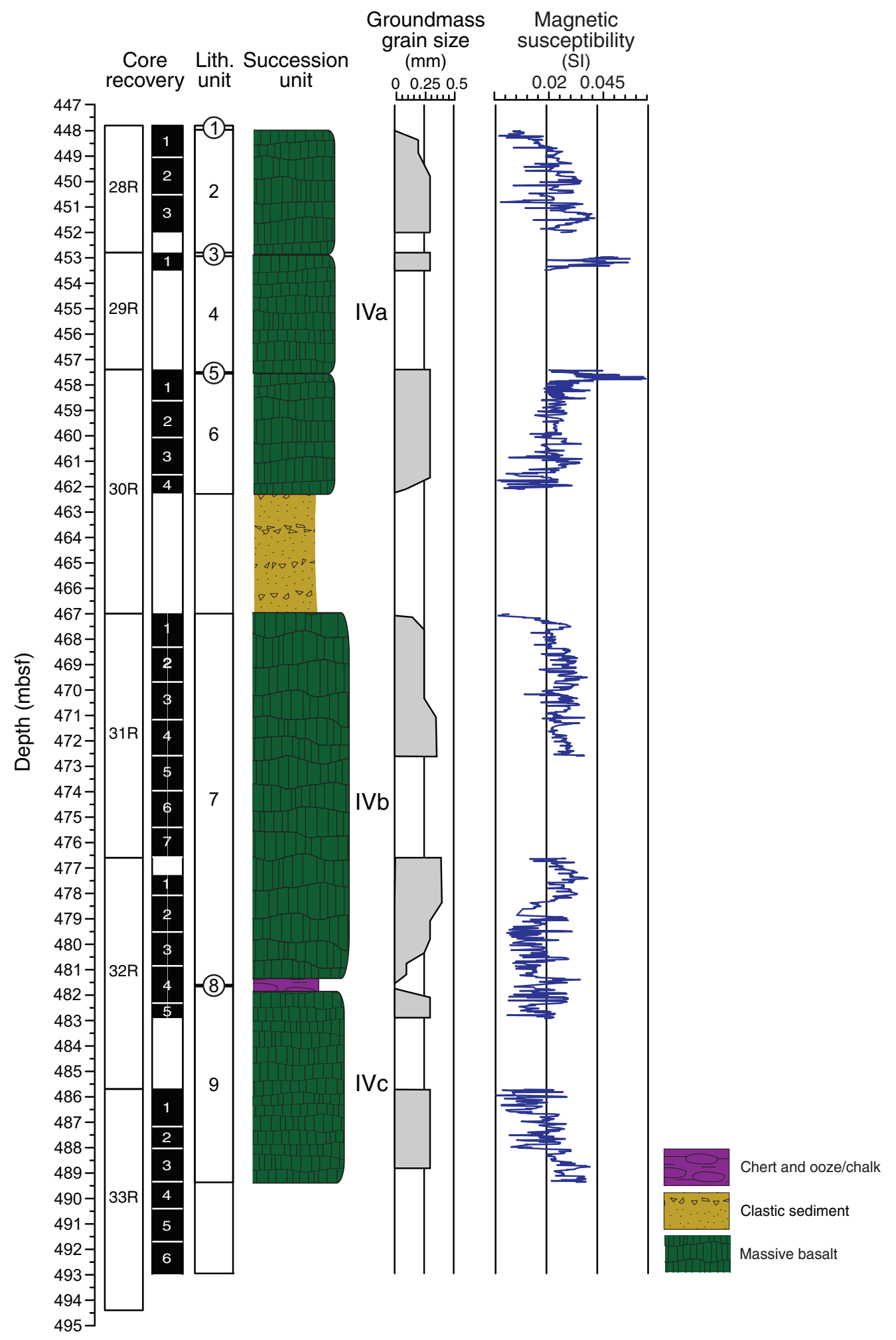


Figure F3. Stratigraphic unit contacts. See the key in Figure F2 for lithologic column pattern definitions. A. Core section images annotated with lithologic unit boundaries for a massive submarine basalt flow in stratigraphic Subunit IVa (Sections 324(198)-1213B-28R-1 through 31R-2). (Continued on next page.)

A

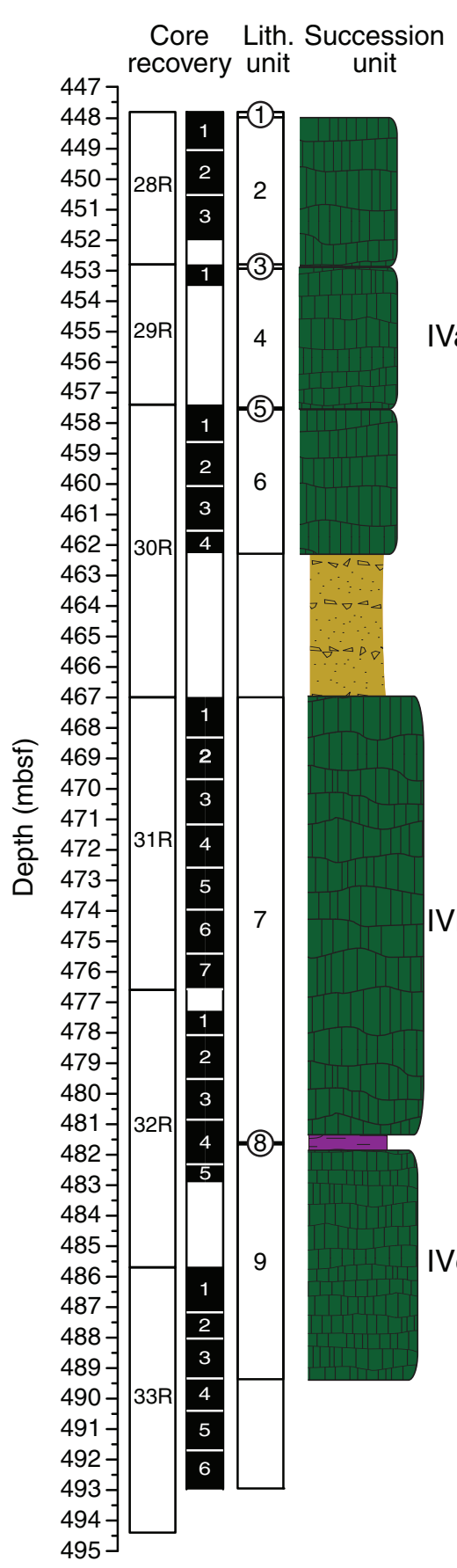

28R-1

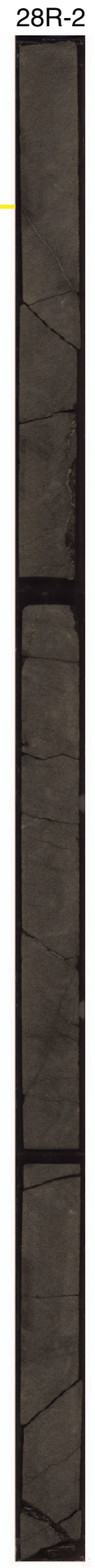

28R-3
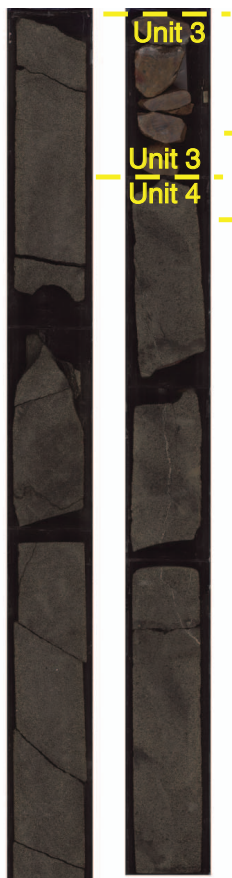

$30 \mathrm{R}-1$

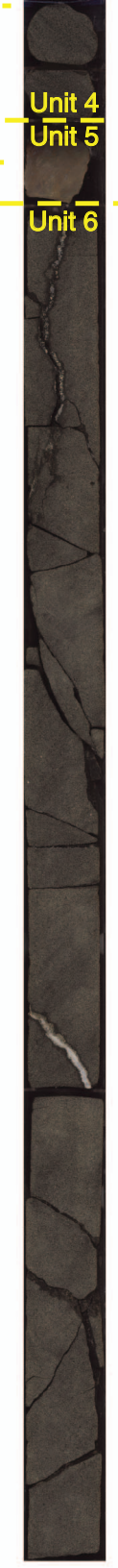

30R-3

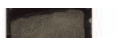

$30 \mathrm{R}-4$

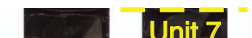

\section{R2}


Figure F3 (continued). B. Core section images annotated with lithologic unit boundaries for two massive submarine basalt flows in stratigraphic Subunits IVb and IVc (Sections 324(198)-1213B-31R-3 through 33R-3).

B

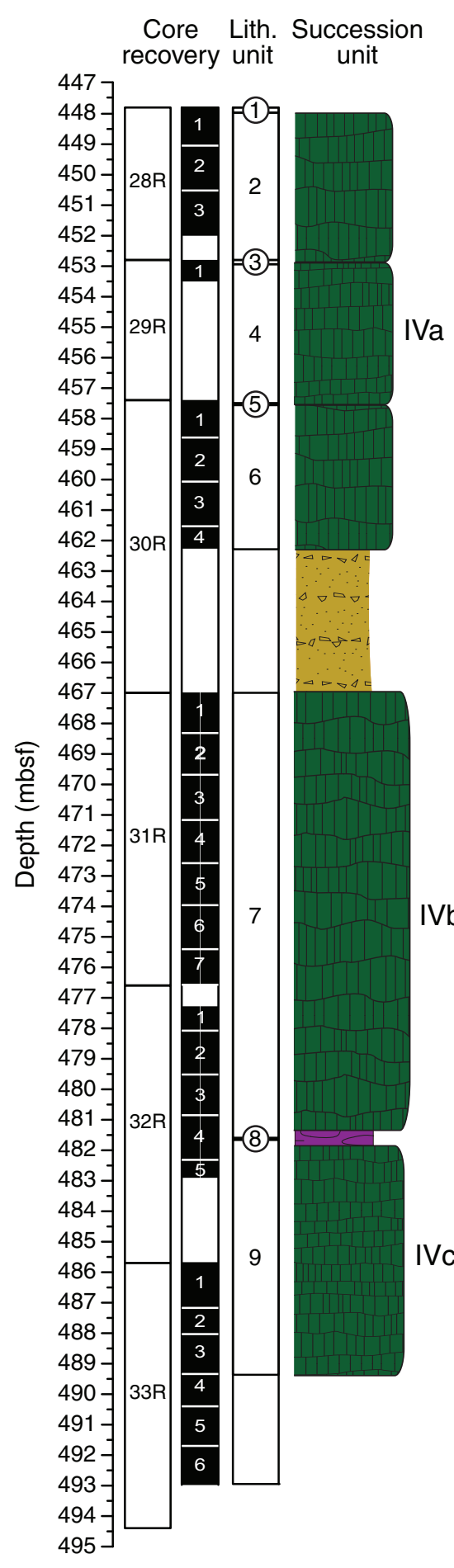

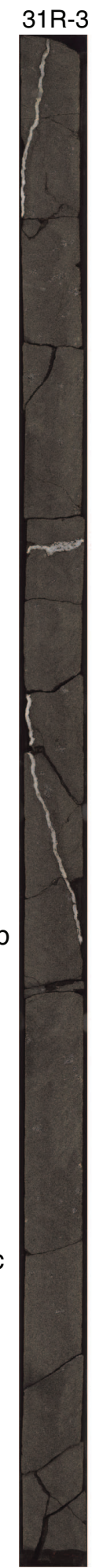
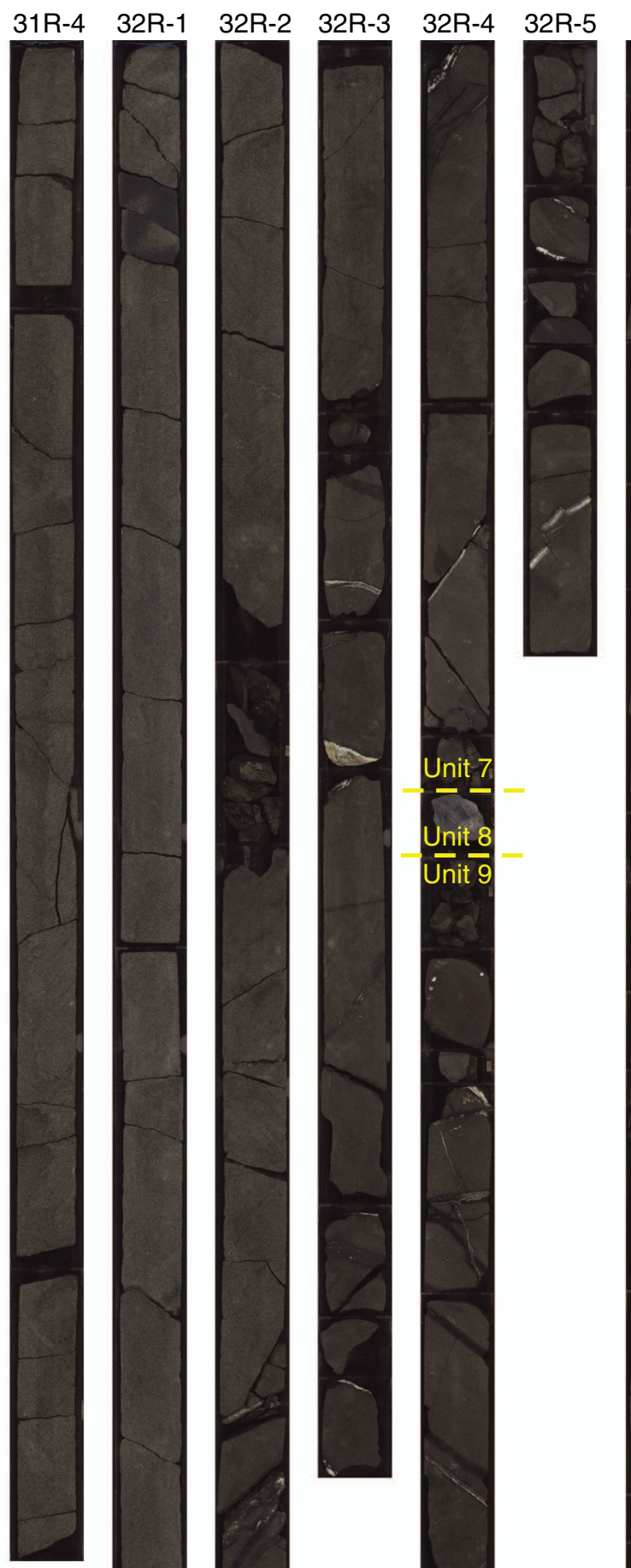
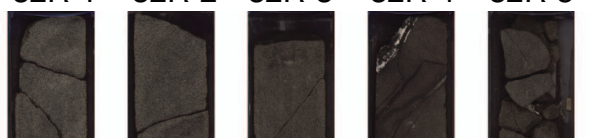

33R-1

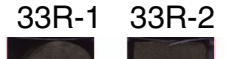

33R-2

33R-3 
Figure F4. Detailed images of all contacts between stratigraphic Subunits IVa and IVc in Hole 1213B.
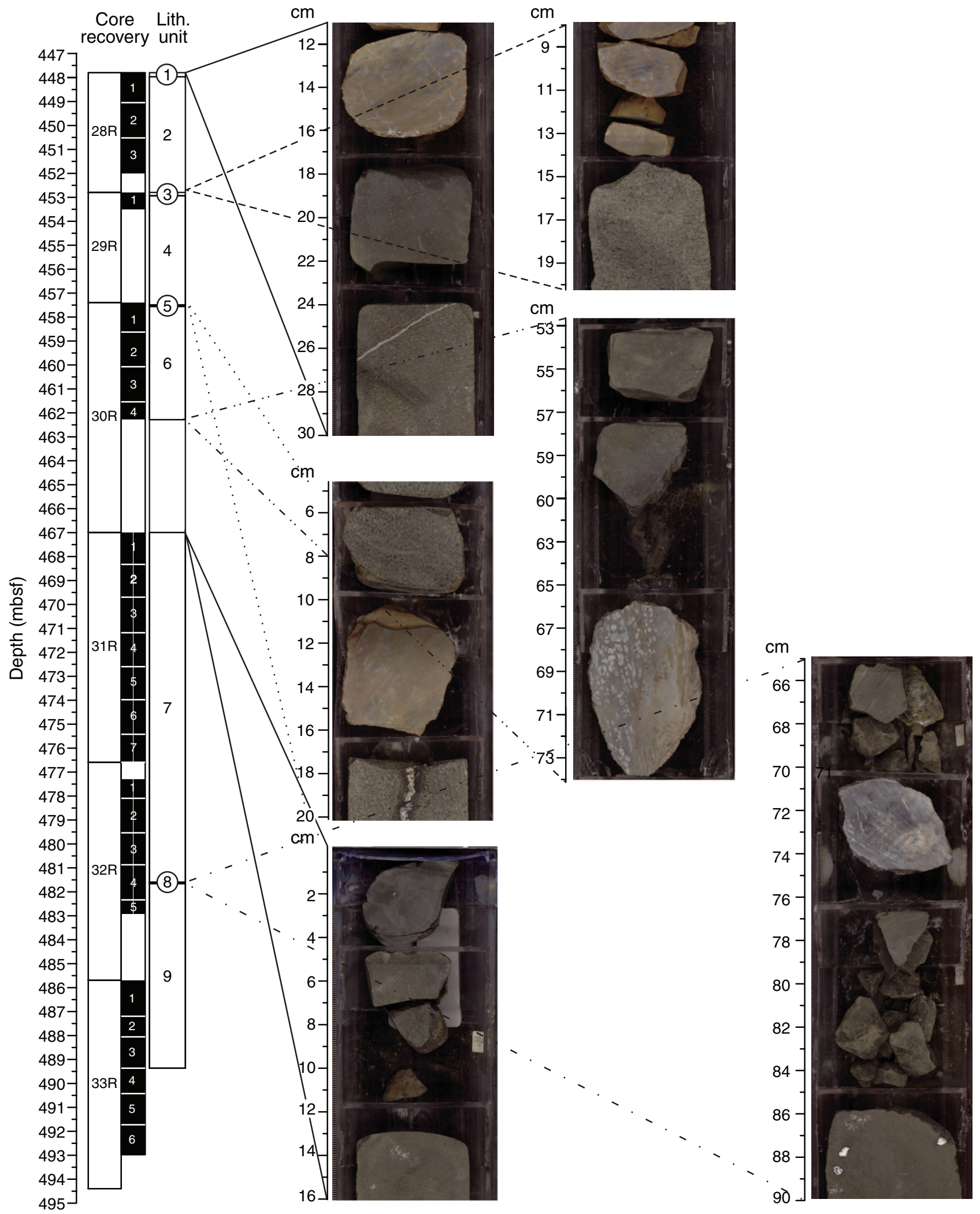
Figure F5. Downhole summary and photomicrographs of texture variations in massive basalt lava flows in Hole 1213B. TS = thin section.
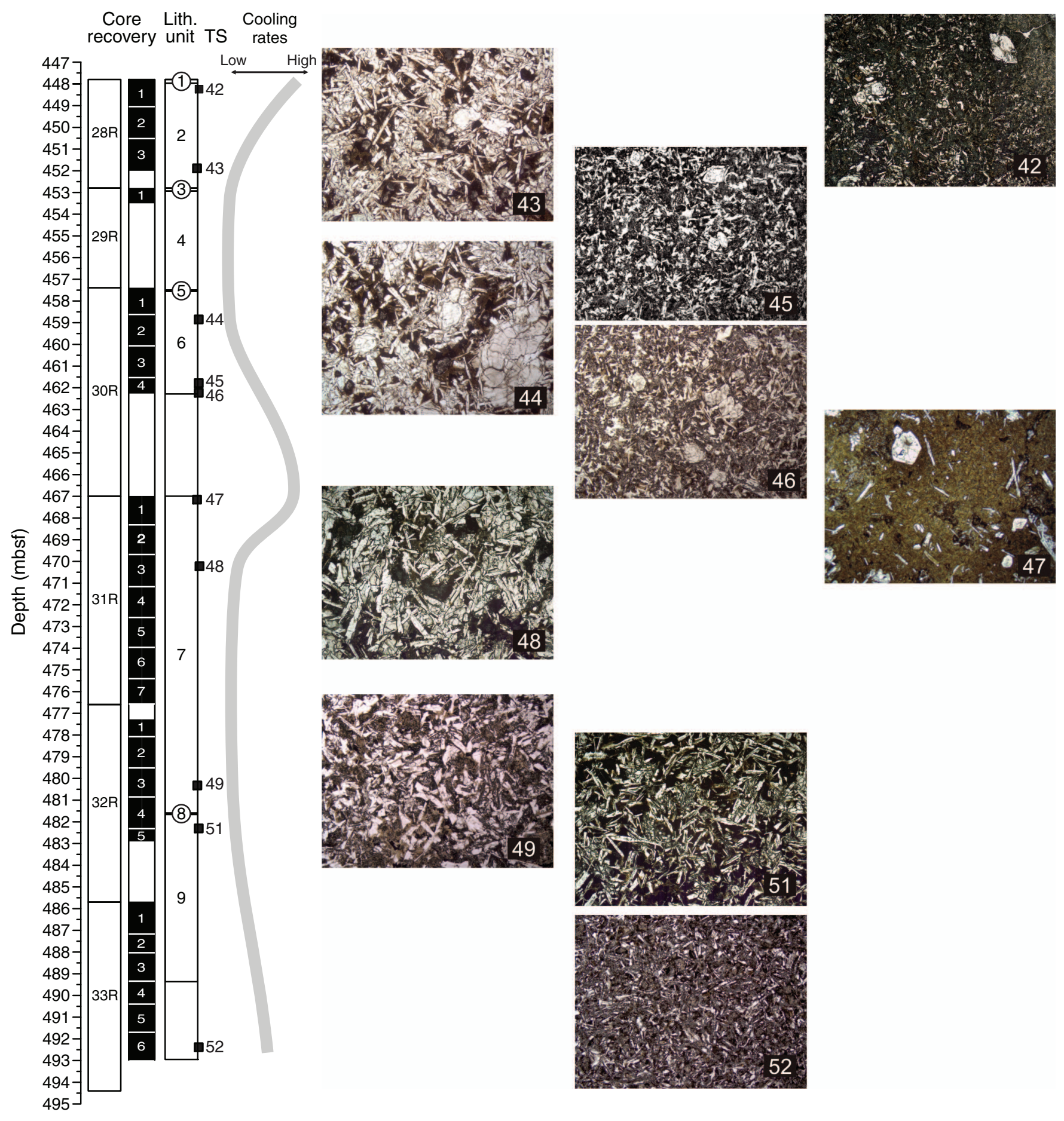
Figure F6. Photomicrographs of three portions of Thin Section 47 (Sample 324(198)-1213B-31R-1, 2-7 cm) at an extrusive-unit margin. Note the increasing crystallinity of coalesced spherulites and increasing grain size of small titanomagnetite with distances from the nearly quenched edge of the thin section of (A) $\sim 1 \mathrm{~mm}$, (B) $\sim 3 \mathrm{~mm}$, and (C) $\sim 20 \mathrm{~mm}$. Plane-polarized light.
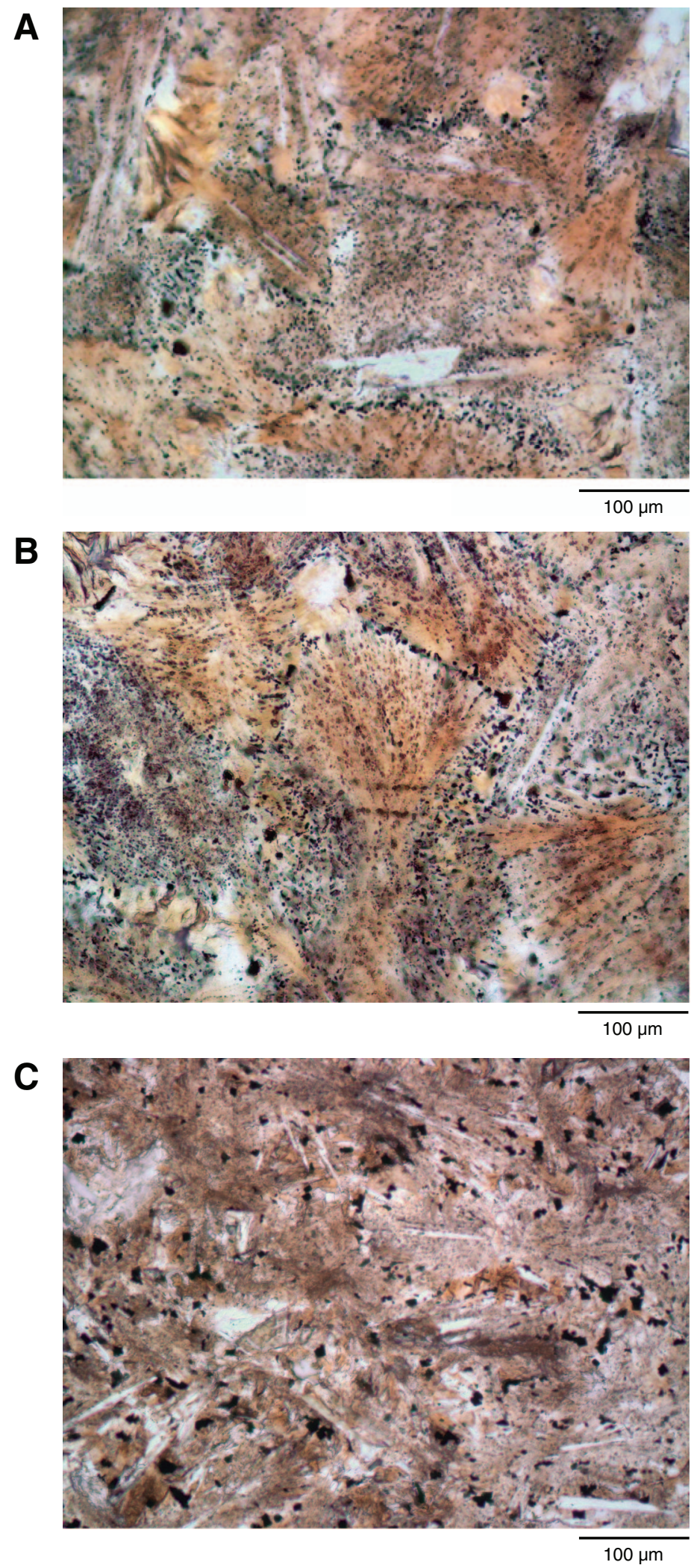
Figure F7. Photomicrographs of development of an interlocking network of plagioclase-clinopyroxene crystal clumps with increasing grain size indicating a decreasing cooling rate. A. Thin Section 47 (Sample 324(198)1213B-31R-1, 2-7 cm). B. Thin Section 42 (Sample 324(198)-1213B-28R-1, 45-48 cm). C. Thin Section 45 (Sample 324(198)-1213B-32R-4, 39-41 cm). D. Thin Section 51 (Sample 324(198)-1213B-32R-4, 131-134 cm). E. Thin Section 49 (Sample 324(198)-1213B-32R-3, 72-75 cm). F. Thin Section 44 (Sample 324(198)-1213B30R-2, 27-38 cm). Plane-polarized light.

A

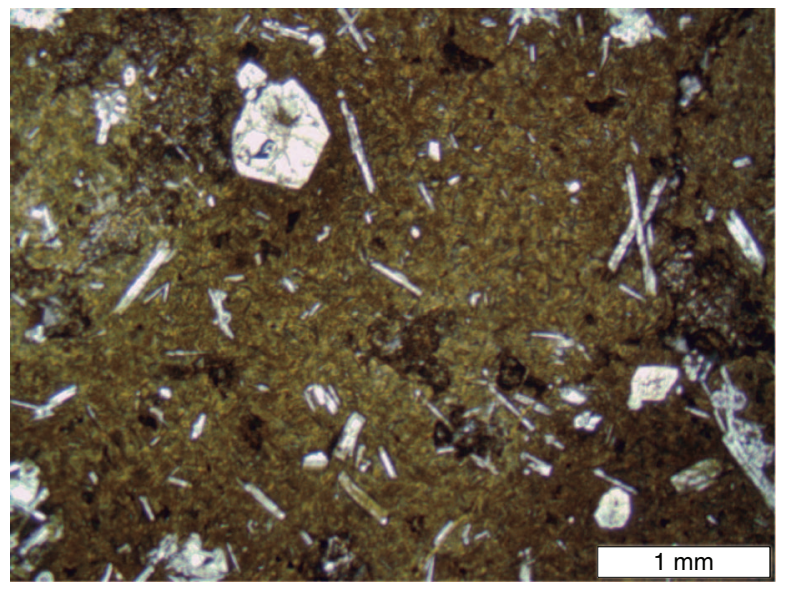

C

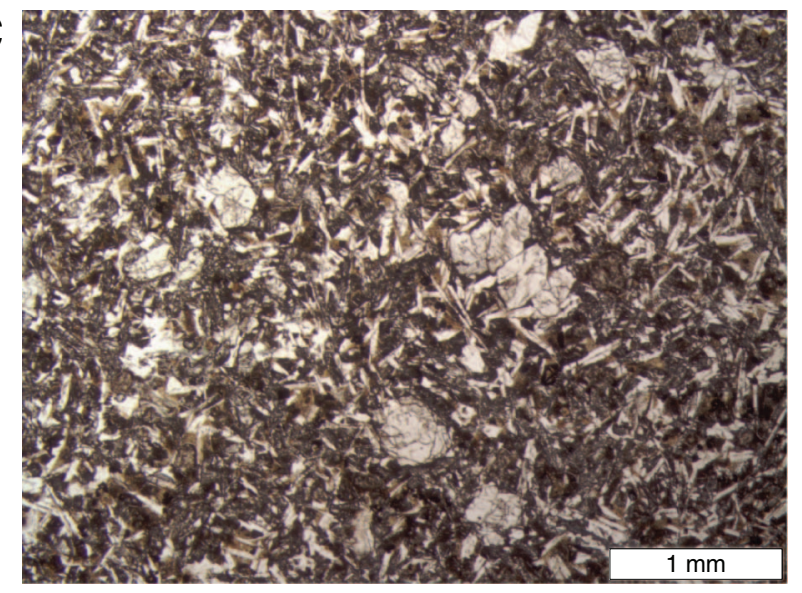

E

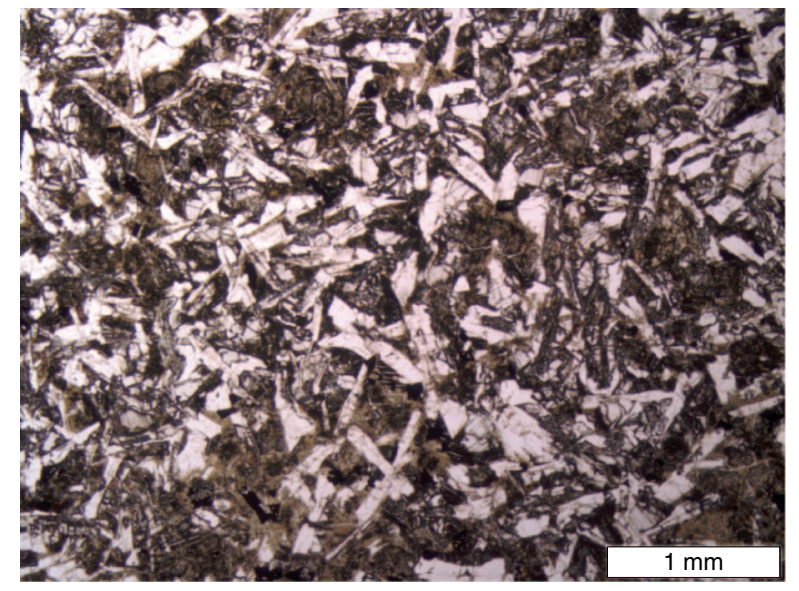

B

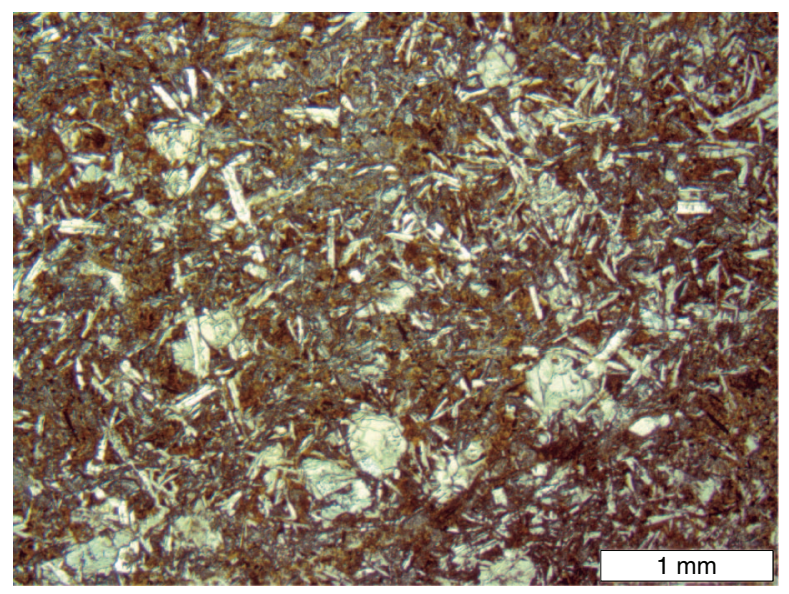

D

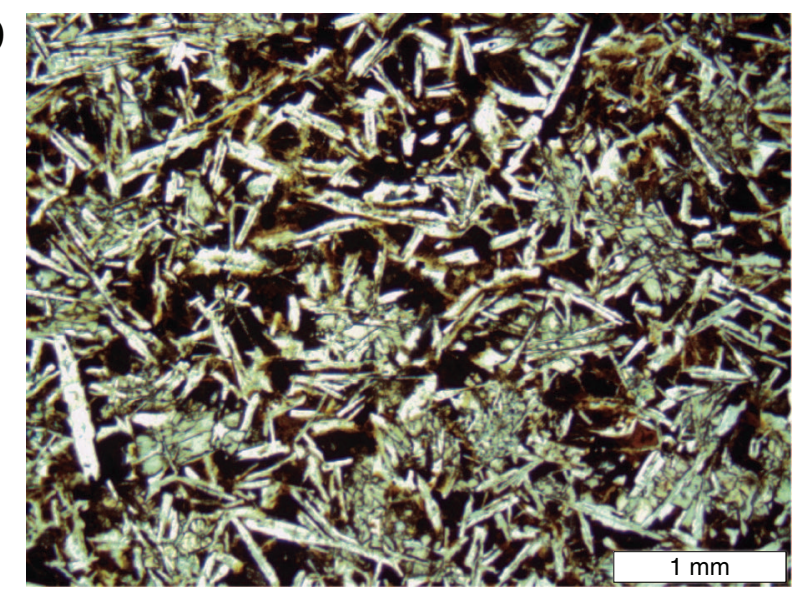

$F$

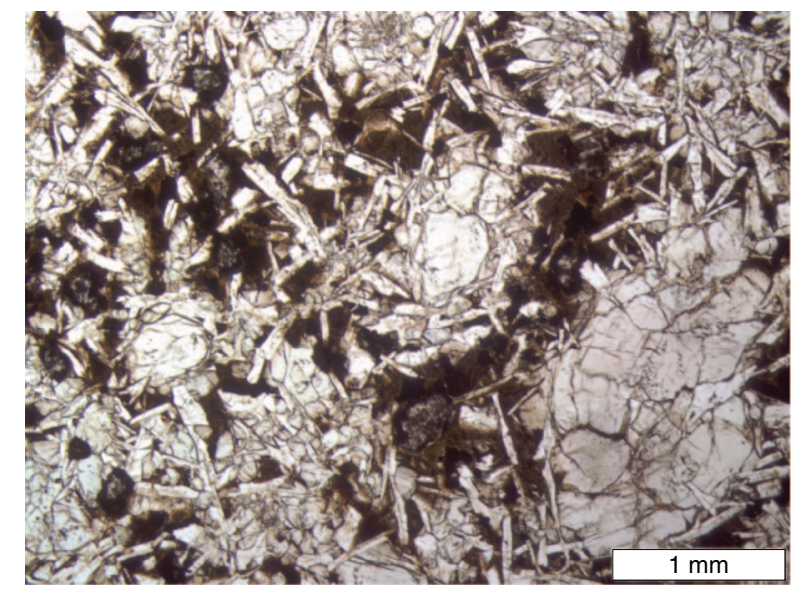


Figure F8. Photomicrographs of clinopyroxene microphenocrysts and crystal clumps. A, B, D, E. Thin Section 47 (Sample 324(198)-1213B-31R-1, 2-7 cm); (A) small euhedral crystal, (B) sector-zoned clinopyroxene, (D) clump of intergrown clinopyroxene and plagioclase, (E) clinopyroxene-plagioclase glomerophyric crystal clump in a finer grained matrix. C. Clinopyroxene phenocryst with irregular overgrowths in medium-trained basalt (Thin Section 45; Sample 324(198)-1213B-32R-4, 38-41 cm). Cross-polarized light.

A

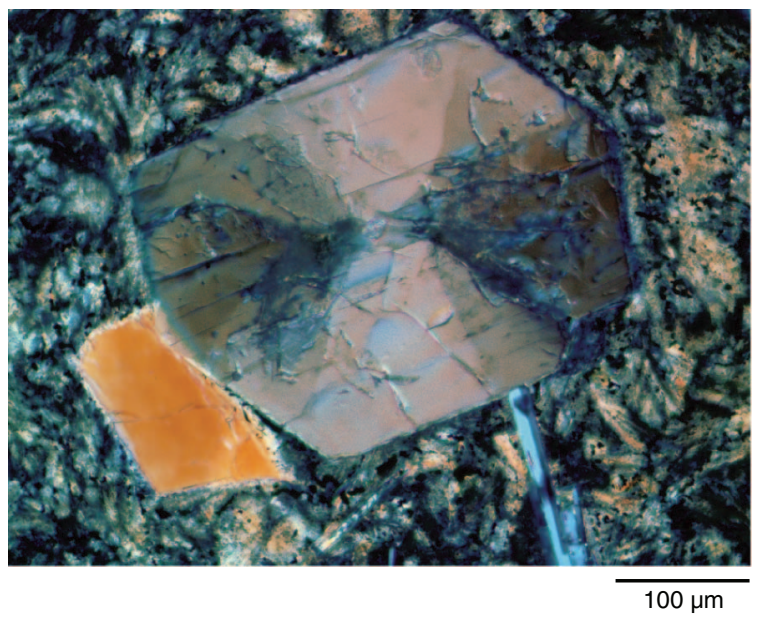

C

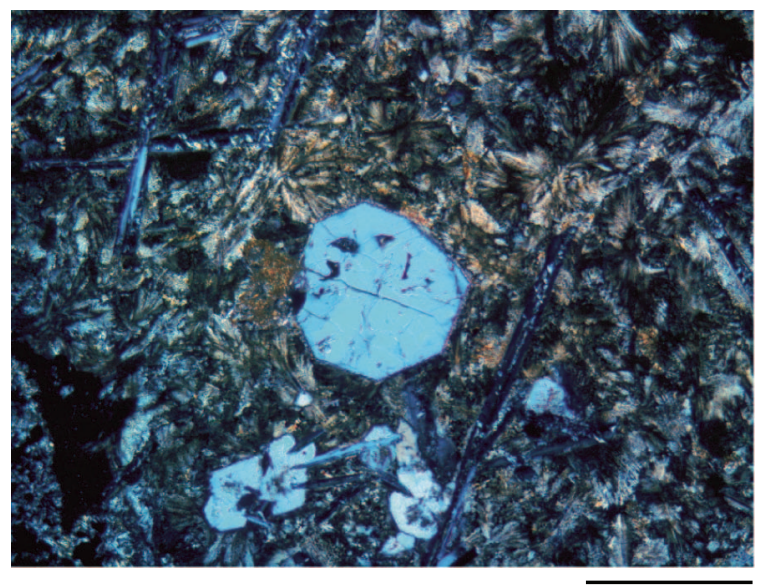

B

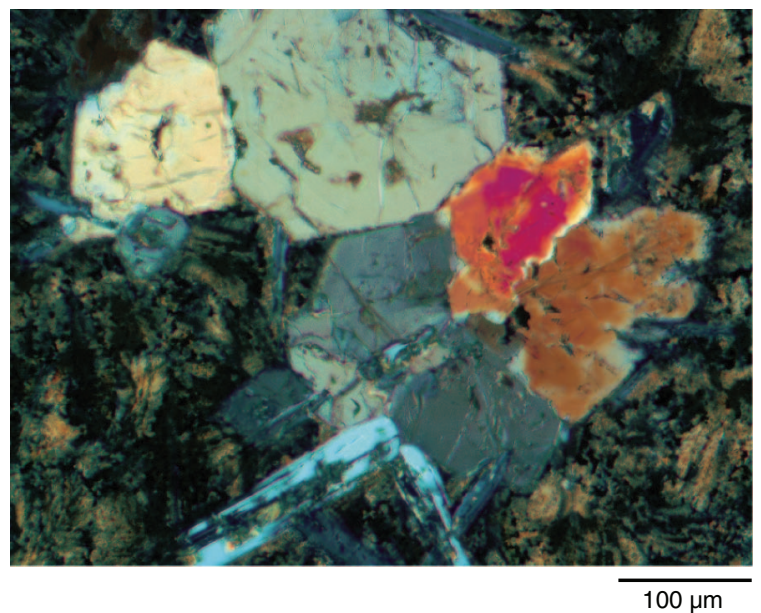

D

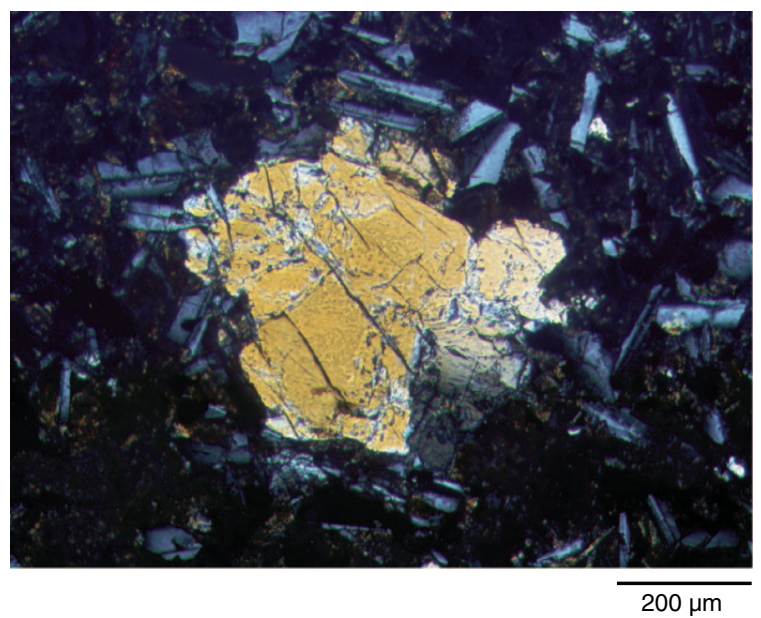

E

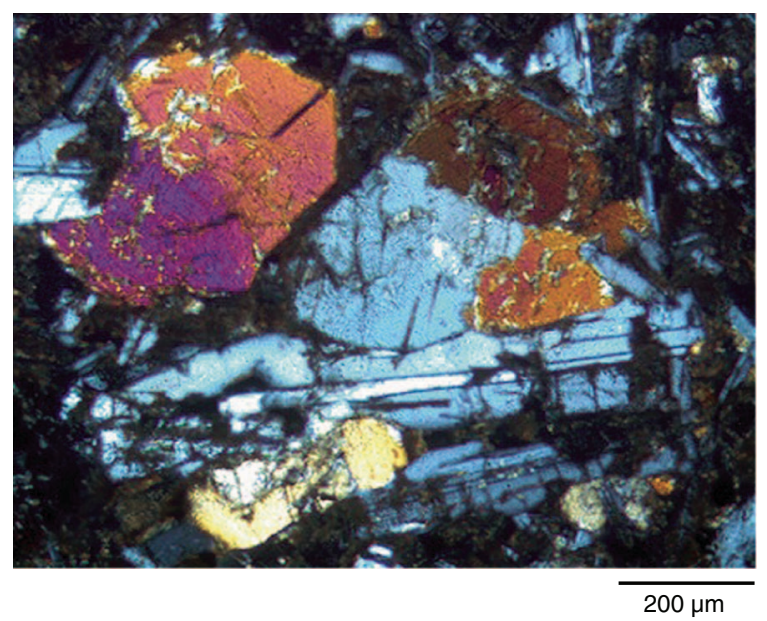


Figure F9. Photomicrographs of plagioclase crystals. A, B. Elongate, tabular, partially skeletal plagioclase crystals in a quickly cooled spherulitic margin (Thin Section 47; Sample 324(198)-1213B-31R-1, 2-7 cm). C, D, E, F. Thin Section 51 (Sample 324(198)-1213B-32R-4, 131-134 cm); (C, D) edge of large skeletal plagioclase xenocryst with a marginal overgrowth on the crystal termination; (E) former melt inclusions now altered to clays, some filled with titanomagnetite, in a core of large plagioclase; (F) anorthositic crystal clump with adcumulus texture developed in plagioclase, most crystals of which contain altered melt inclusions showing as small dark gray nonreflective patches. Note the overgrowth rim at the bottom of the image. A, B, and D are under cross-polarized light, $\mathrm{C}$ and $\mathrm{E}$ are under plane-polarized light, and $\mathrm{F}$ is under reflected light.

\section{A}

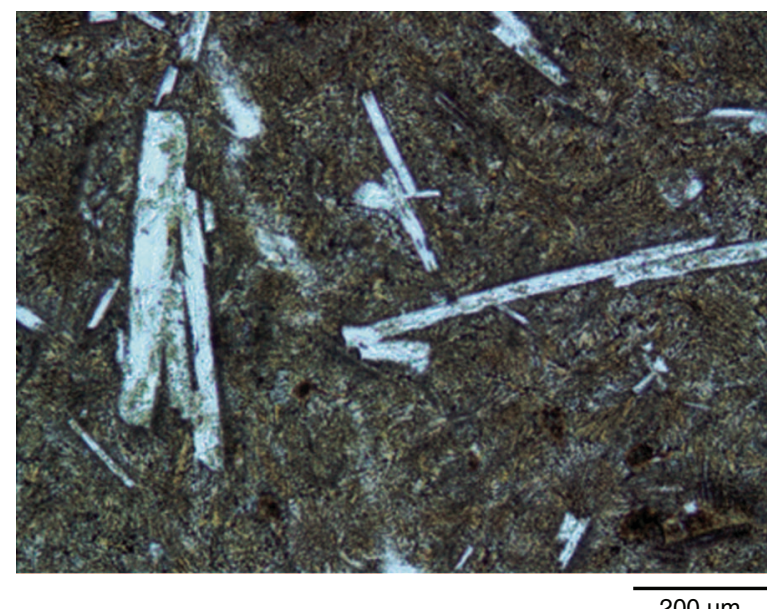

C

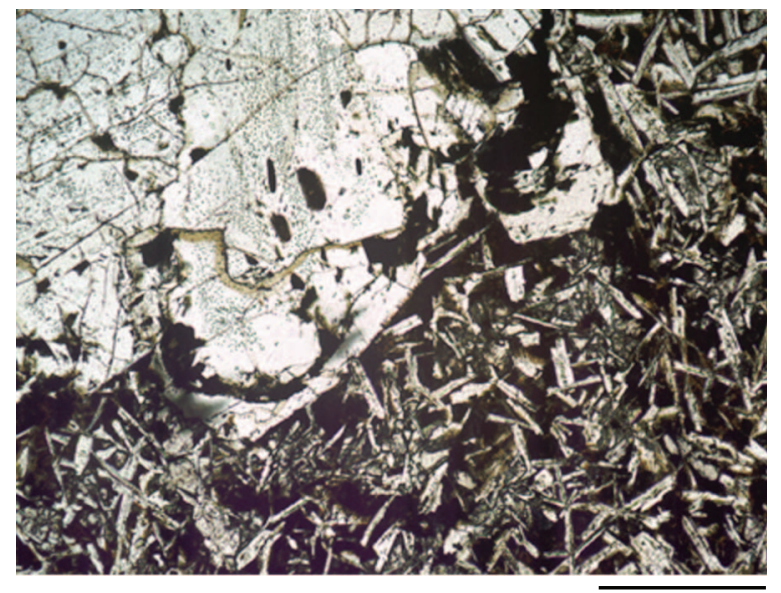

$500 \mu \mathrm{m}$

E

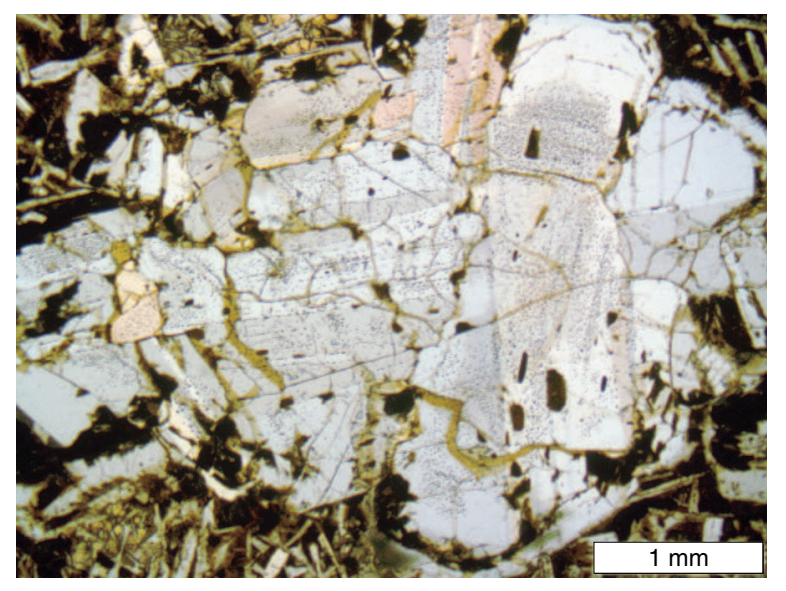

B

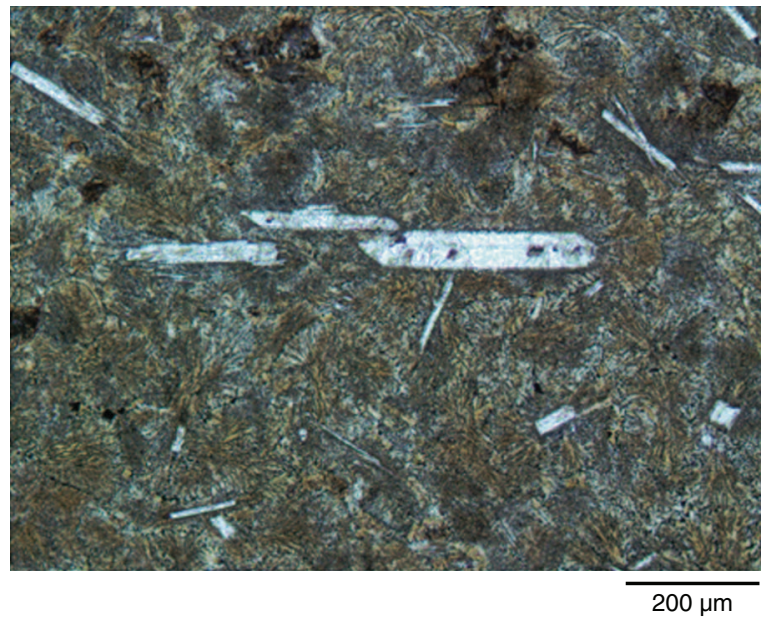

D

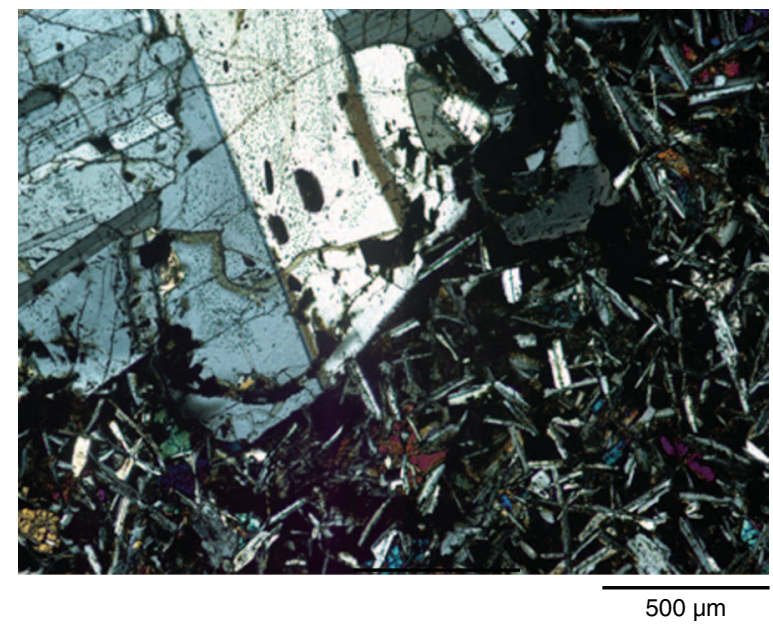

$F$

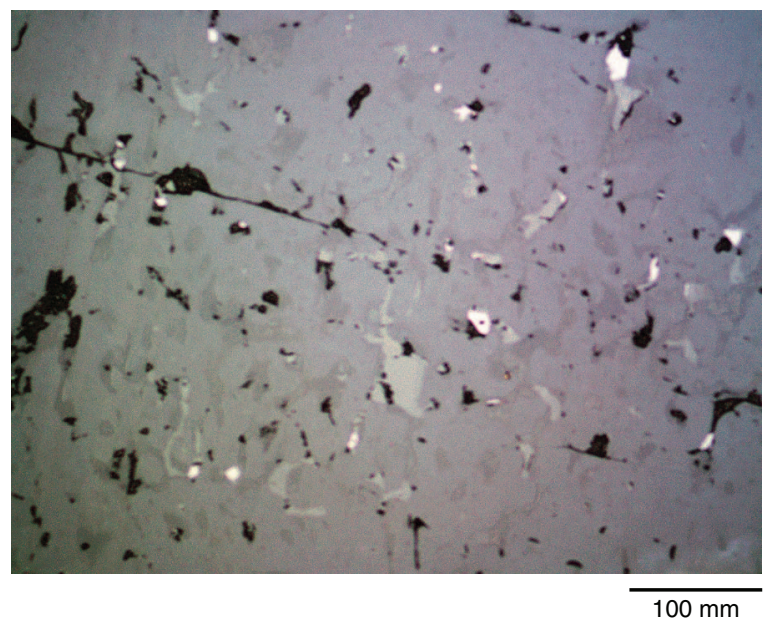


Figure F10. Photomicrographs of examples of skeletal titanomagnetite developed in coarser grained rocks of Hole 1213B. A. Equant skeletal grains, possibly cross-sections of longer chains (Thin Section 42; Sample 324(198)-1213B-28R-1, 45-48 cm). B, C. Titanomagnetite intergrown with plagioclase (Thin Section 45; Sample 324(198)-1213B-32R-4, 39-41 cm). D. Long curving titanomagnetite chain spanning the width of an intersertal space (Thin Section 43; Sample 324(198)-1213B-28R-3, 143-145 cm). E. Titanomagnetite chain spanning the shorter distance across an intersertal space, rooted in clinopyroxene (light gray reflectivity compared with darker gray for plagioclase) (Thin Section 48; Sample 324(198)-1213B-31R-3, 73-75 cm). Cross-polarized light.

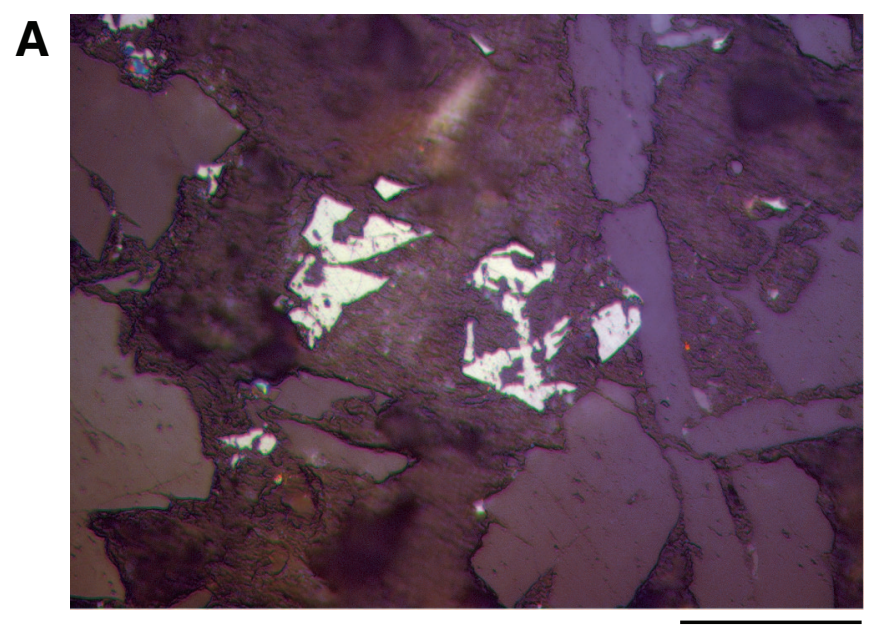

$50 \mu \mathrm{m}$

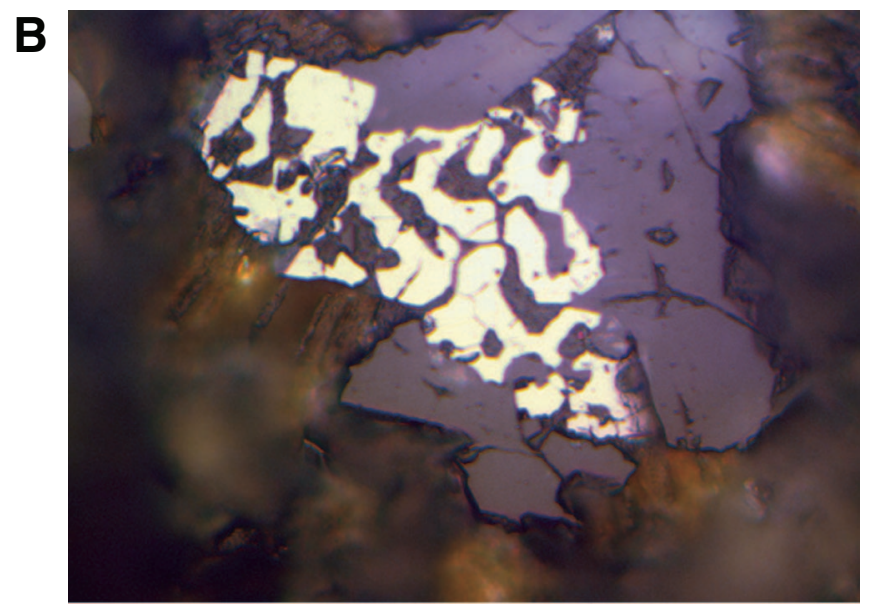

$50 \mu \mathrm{m}$
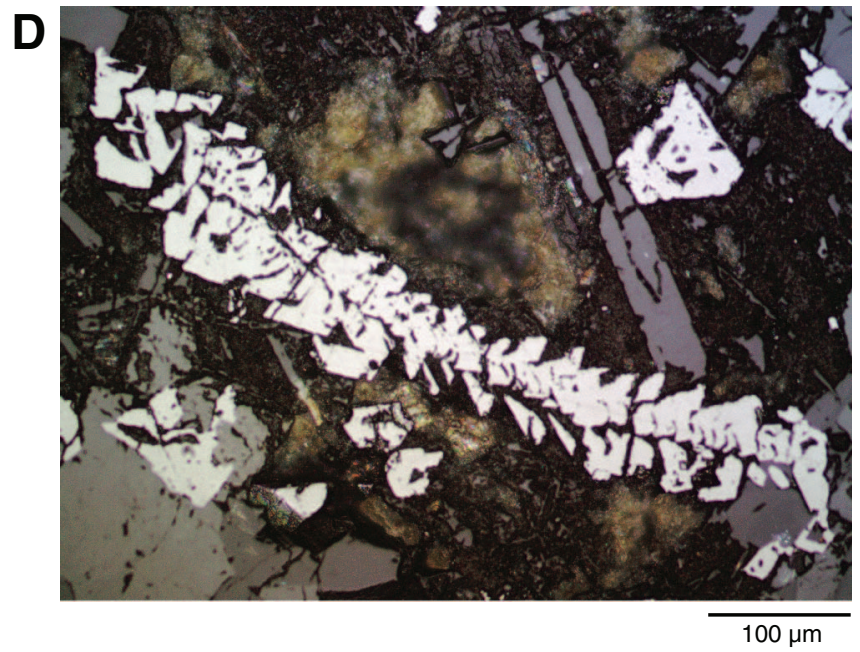

C

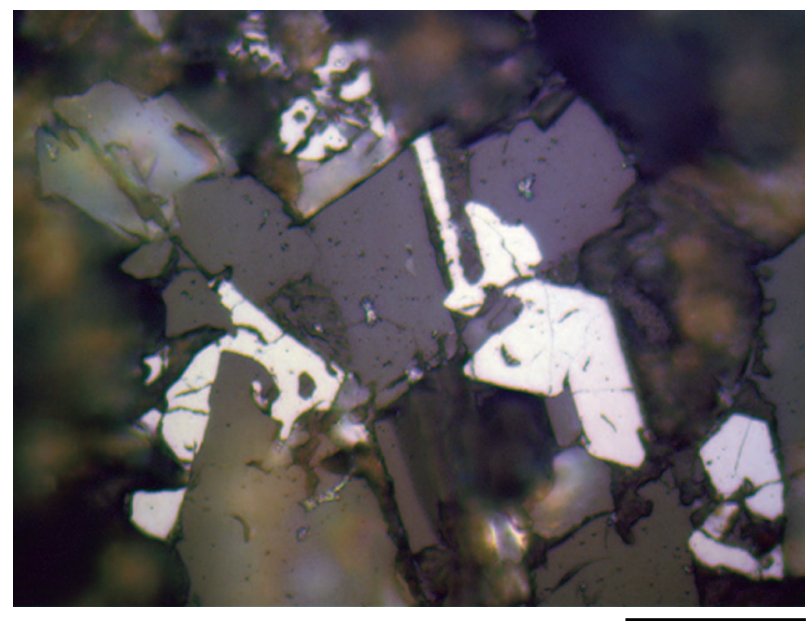

$50 \mu \mathrm{m}$

E

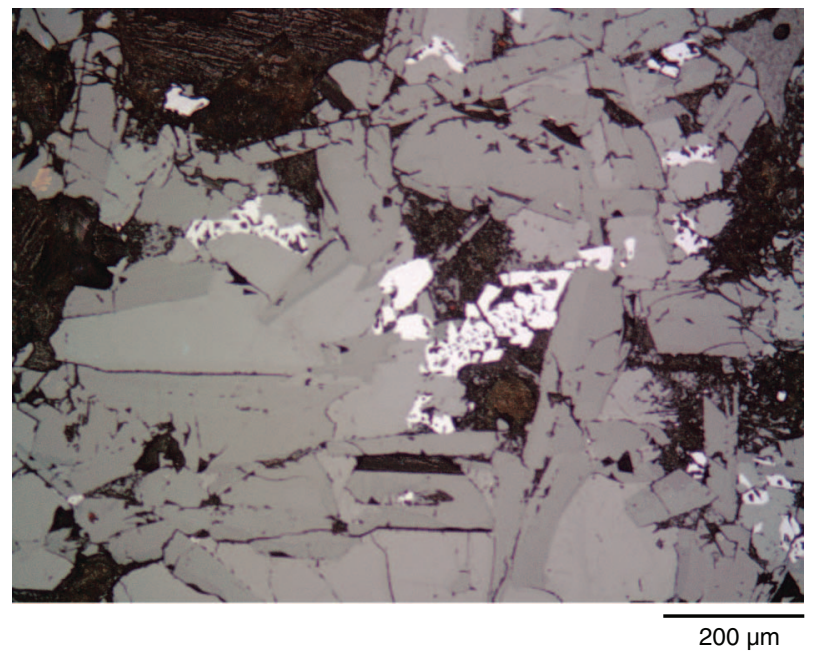


Figure F11. Photomicrographs of secondary phases and alteration. A, B. Fine-grained basalt with groundmass composed of relatively unaltered plagioclase and pyroxene microcrysts and a glassy mesostasis completely altered to brown anisotropic clay minerals (Thin Section 49; Sample 324(198)-1213B-32R-3, 72-75 cm). C. Glassy mesostasis partially replaced by calcite (Thin Section 48; Sample 324(198)-1213B-31R-3, 73-75 cm). D. Partially altered plagioclase phenocryst. The inner part is relatively fresh, whereas the rim of the phenocryst has been completely replaced, likely by a Na- and/or K-richer feldspar associated with some sericite (Thin Section 52; Sample 324(198)-1213B-33R-6, 106-108 cm). E. Calcite vein showing both blocky and fibrous habits (Thin Section 48; Sample 324(198)-1213B-31R-3, 73-75 cm). A and E are under plane-polarized light; B, $\mathrm{C}$, and $\mathrm{D}$ are under cross-polarized light.
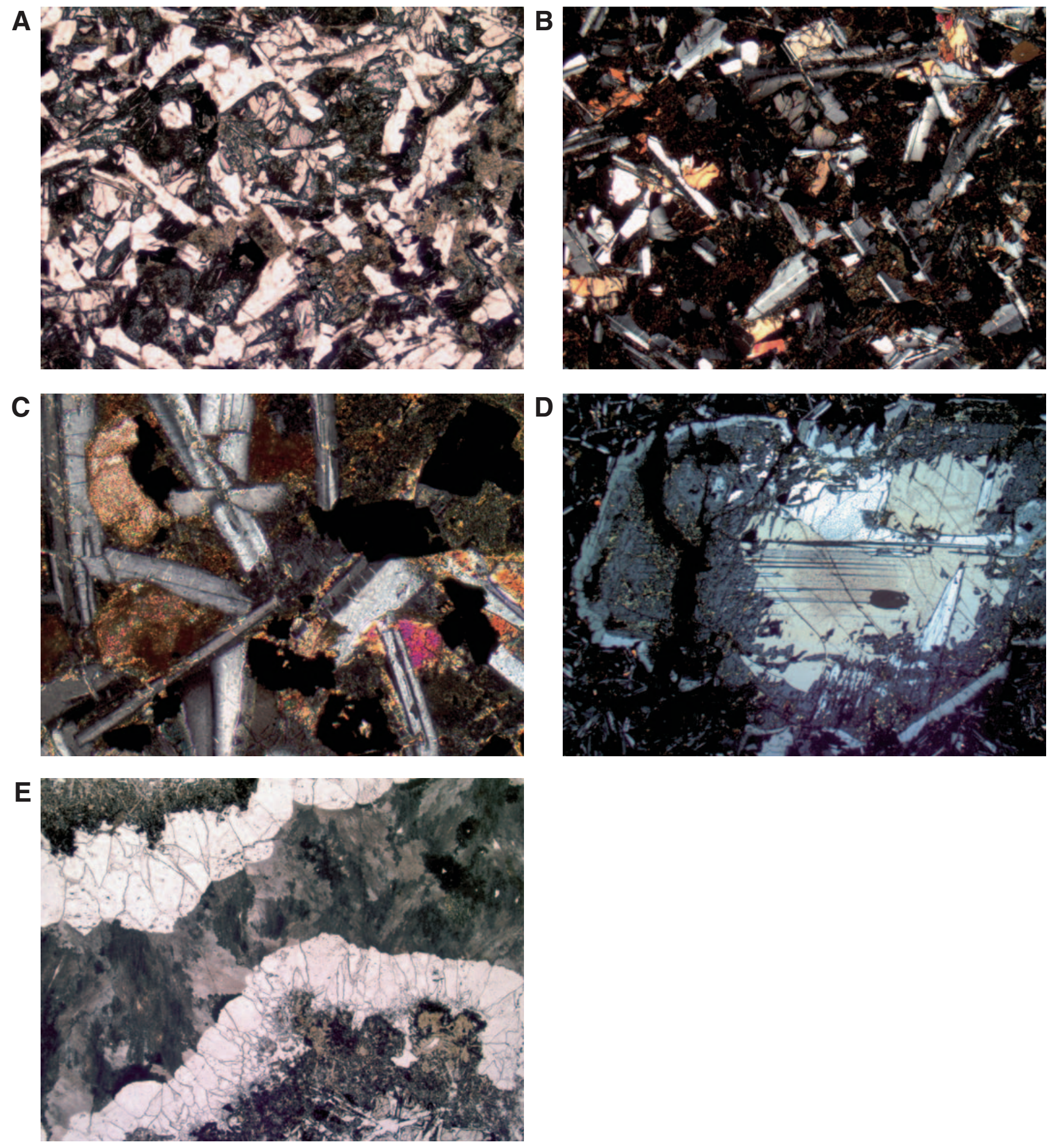
Table T1. Site 1213 stratigraphic and lithologic units described during Expedition 324.

\begin{tabular}{|c|c|c|c|c|c|c|}
\hline \multicolumn{2}{|c|}{ Unit } & \multirow{2}{*}{$\begin{array}{l}\text { Core, section, } \\
\text { interval }(\mathrm{cm})\end{array}$} & \multicolumn{2}{|c|}{ Contact depth (mbsf) } & \multirow[b]{2}{*}{ Rock type } & \multirow{2}{*}{$\begin{array}{l}\text { Thickness } \\
(\mathrm{m})\end{array}$} \\
\hline Stratigraphic & Lithologic & & Upper & Lower & & \\
\hline & & $24(198)-1213 B-$ & & & & \\
\hline III & 1 & & & 448.0 & Baked chert & \\
\hline \multirow[t]{5}{*}{ IVa } & 2 & $28 \mathrm{R}-1,17$ & 448.0 & 452.0 & Massive basalt flow & 14.3 \\
\hline & 3 & $29 \mathrm{R}-1,0$ & 452.8 & 452.9 & Baked cherty sediment & \\
\hline & 4 & $29 \mathrm{R}-1,13$ & 452.9 & 457.5 & Massive basalt flow & \\
\hline & 5 & $30 \mathrm{R}-1,10$ & 457.5 & 457.6 & Baked cherty sediment & \\
\hline & 6 & $30 \mathrm{R}-1,17$ & 457.6 & 462.3 & Massive basalt flow & \\
\hline \multirow[t]{2}{*}{$\mathrm{IVb}$} & 7 & $31 \mathrm{R}-1,0$ & 467.0 & 481.6 & Massive basalt flow & 14.6 \\
\hline & 8 & $32 \mathrm{R}-4,70$ & 481.6 & 481.7 & Sediment (metachert) & \\
\hline IVc & 9 & $32 \mathrm{R}-4,77$ & 481.7 & 493.0 & Massive basalt flow & 11.3 \\
\hline
\end{tabular}

